\title{
PENGARUH DIMENSI KEPRIBADIAN THE BIG FIVE PERSONALITY TERHADAP ORGANIZATIONAL CITIZENSHIP BEHAVIOR (OCB)
}

\author{
Ria Lestari Pangastuti \\ Universitas Kadiri \\ ria_lestari@unik-kediri.ac.id
}

\begin{abstract}
The reasearch aim is for analizing the influence of personality dimension "The Big Five Personality" towards ORGANIZATIONAL Citizenship Behavior (OCB) (Studi Case Of Student Affairs Employees At X University). Population of this research is all employees of $X$ University and sample is the employees who are at student affairs unit (50 people). The data were collected by sharing the quesioner to 50 respondents. The analysis of this research is Partial Least Square Structural EQUTION Model (PLSSEM). Analysis result of PLS-SEM is there is significant influence of personality dimension, "The Big Five Personality" among five personality dimensions, alturism has the highest significance.
\end{abstract}

Keywords: Personality Dimension, organizational citizenship behaviors (OCB).

\begin{abstract}
ABSTRAK
Penelitian ini bertujuan untuk menganalisis pengaruh dimensi kepribadian "The Big Five Personality" terhadap Organizational Citizenship Behavior (OCB) (Studi Kasus karyawan bidang kemahasiswaan Universitas X). Populasi dalam penelitian ini adalah seluruh karyawan yang ada di Universitas $\mathrm{X}$, dan sampelnya adalah karyawan bidang kemahasiswaan yang berjumlah 50 orang. Pengumpulan data dilakukan dengan menyebarkan kuesioner kepada 50 responden. Analisis dalam penelitian ini adalah Partial Least Square Structural Eqution Model (PLS-SEM). Hasil Analisis PLS-SEM terdapat pengaruh yang signifikan pengaruh dimensi kepribadian the big five personality terhadap OCB. Dari 5 dimensi kepribadian yang ada alturism adalah dimensi yang memiliki tingkat signifikan tertinggi. Sedangkan untuk OCB openness to experience yang memiliki tingkat signifikan tertinggi. Dari sini dapat disimpulkan apabila univeritas ingin meningkatkan OCB karyawannya, maka dapat dilakukan dengan meningkatkan openness to experience atau sikap terbukanya dalam menerima sesuatu.
\end{abstract}

Kata Kunci : Dimensi Kepribadian, organizational citizenship behaviors (OCB).

\section{PENDAHULUAN}

Ada beberapa hal dalam organisasi yang mendorong tercapainya tujuan organisasi jangka pendek maupun jangka panjang salah satunya adalah sumber daya manusia yang terkait dengan karyawan yang bekerja di organisasi tersebut.

Sumber daya manusia merupakan faktor yang paling penting, karena dengan sumber daya manusia yang bermutu dapat meningkatkan efektivitas dan efisiensi 
kinerja. Dunia kerja saat ini menginginkan karyawan yang bersifat fleksibel yang artinya karyawan tersebut harus mampu bekerja sesuai dengan tuntutan perkembangan, bahkan melebihi apa yang diinginkan organisasi.

Saat ini karyawan dituntut untuk bisa bekerja secara tim atau team work dengan tujuan untuk memaksimalkan hasil kerja. Cara kerja ini dianggap sangat mempunyai potensi untuk mencapai tujuan lebih cepat bila dibandingkan dengan metode kerja secara individu yang bertujuan meringankan beban kerja dalam bekerja. Keberhasilan kerja secara team work bisa dilihat dari karakteristik kepribadian yang dimiliki karyawan yang bekerja di organisasi atau perusahaan tersebut.

Agar karyawan dapat bekerja secara tim dengan baik, maka organisasi harus dapat menumbuhkan perilaku - perilaku positif karyawan terhadap pekerjaannya dan diluar pekerjaan yang terkait dengan organisasi dimana mereka bekerja. Perilaku perilaku positif yang tidak disyaratkan disebut juga sebagai perilaku ekstra-role atau yang dikenal dengan organizational citizenship behaviors (OCB). Borman dan Motowidlo (dalam Novliadi, 2006) menyatakan bahwa OCB ini adalah gambaran perilaku karyawan yang dapat meningkatkan kinerja, serta dapat mengurangi konflik dalam bekerja. George (dalam Kelana, 2009) juga menyatakan bahwa OCB penting bagi keberhasilan sebuah organisasi organisasi tidak dapat mengantisipasi seluruh perilaku organisai hanya dengan mengandalkan deskripsi kerja yang dinyatakan secara formal saja, maka pimpinan organisasi perlu memahami karakter kepribadian para karyawannya dengan mengenal dan memahami dimensi kepribadian yang terangkum dalam "The Big Five Personality atau five factor model (FFM).

Karyawan yang bekerja dibidang pelayanan pendidikan adalah karyawan yang bersinggungan langsung dengan mahasiswa. Kunci kesuksesan dalam pekerjaan ini tergambar dari kemampuan interaksi karyawan dalam menghadapi mahasiswa. Dalam berinteraksi karaywan harus siap secara fisik dan mental.

Dari uraian tersebut maka penulis ingin meneliti lebih lanjut Pengaruh Dimensi Kepribadian “The Big Five Personality” Terhadap Organizational Citizenship Behavior (OCB) Studi kasus pada petugas pelayanan mahasiswa Universitas X di Kota Kediri. Sedangkan tujuan penelitian ini adalah peneliti ingin melihat besar pengaruh Dimensi Kepribadain The Big Five Personality (X) terhadap Organizational Behavior Citizenship (OCB) (Y). 


\section{TINJAUAN PUSTAKA}

\section{Kepribadian The Big Five Personalty}

\section{Pengertian Kepribadian}

Kepribadian adalah refleksi diri seseorang yang terbentuk karena pengaruh sosial dalam kehidupan sehari-hari. Faktor keturunan dan faktor lingkungan dimana orang tersebut tinggal dan bersosialisasi adalah salah satu pembentuk kepribadian seseorang. Sambung \& Iring (2014) "kepribadian adalah cara seseorang merespon sesuatu yang terjadi, bersifat unik, dinamis, yang merupakan hasil interaksi fisik/genetik, environment, emotional, cognition, serta menunjukan cara individu dalam mengelola (management) waktunya".

Ada beberapa pendekatan yang dapat digunakan untuk mengidentifikasi kepribadian seseorang. Diantaranya adalah teori The Big Five Personality. Berdasarkan penelitian yang telah dilakukan Costa dan McRae "The Big Five Personality" dimensi kepribadian individu dapat dibedakan berdasarkan usia, jenis kelamin, dan ras seseorang. Selain faktor keturunan juga berpengaruh besar terhadap keperibadian.

\section{Dimensi kepribadian}

Robbins (2008) "mengungkapkan bahwa setiap individu memiliki kepribadian yang berbeda satu dengan yang lainnya. Dimensi The Big 5 Personality mewakili karakteristik yang terdapat dalam kebanyakan orang. Kita dapat melihat kepribadian seseorang dengan cara membandingkan 5 dimensi yang disebut dengan five factor model atau FFM antara lain sebagai berikut" :

1. Extroversion (sosialisasi)

Dimensi yang menunjukkan individu yang suka bersosialisasi. Karakter individu yang suka bersosialisasi sangat mudah mengerjakan pekerjaan dengan cara berkelompok, tingkat individualismenya juga rendah.

2. Agreeableness (mudah akur atau mudah bersepakat)

Dimensi ini menunjukkan individu yang mudah bersepakat. Orang - orang yang masuk dalam dimensi ini adalah kriteria orang yang rendah hati dan mau menerima saran dari orang lain yang dianggap lebih mampu dan lebih benar dari pendapatnya sendiri. 
3. Conscientiousness (sifat berhati-hati)

Dimensi ini menjelaskan sifat individu yang bertanggungjawab terhadap pekerjaan dan selalu berhati-hati dalam bertindak.

4. Emotional stability (stabilitas emosional)

Merupakan kecenderungan seseorang mengalami keadaan tenang, aman dan tidak mudah khawatir saat menyelesaikan tugas kerjanya.

5. Openness to experience (terbuka terhadap hal-hal yang baru)

Sikap spesifik yang dicakupnya adalah intelektual, imajinatif, penasaran, dan berpikiran luas. Orang-orang dalam dimensi ini merupakan orang yang mempunyai sifat kreatif, kemampuan majunya tinggi dan rasa ingin tahunya besar terhadap sesatu yang berkaitan dengan hasil kerjanya.

\section{Organizational Citizenship Behavior (OCB)}

\section{Pengertian Organizational Citizenship Behavior (OCB)}

Menurut (Robbins dan Judge, 2008) “ OCB atau yang disebut dengan perilaku kewargaan organisasi adalah perilaku dimana pilihan yang tidak menjadi bagian dari kewajiban kerja formal seorang karyawan, namun mendukung berfungsinya organisasi tersebut secara efektif". Sedangkan Basrah (2012) menyatakan ada beberapa hal yang mempengaruhi OCB adalah perbedaan terkait dengan kemampuan, sikap individu dalam bekerja, sikap karyawan dalam menjalankan pekerjaannya.

Menurut Organ (2006) OCB dibangun dari lima dimensi yang masingmasingnya bersifat unik, yaitu:

1. Altruism, adalah sikap saling tolong menolong

2. Civic virtue, adalah saling mendukung dalam bekerja

3. Conscientiousness, adalah bertanggung jawab untuk menghasilkan pekerjaan yang terbaik untuk organisasi

4. Courtesy, adalah rasa suka membantu meringankan beban kerja oranglain

5. Sportsmanship, adalah gambaran sportivitas karyawan dalam bekerja Berikut adalah skala pengukuran Morison (1994) yang dapat dijadikan sebagai kisi-kisi instrumen untuk mengetahui OCB karyawan:

Kategori 1 Altruism meliputi:

1. Suka menolong sesama, 
2. Saling mengantikan peran rekan kerja ketika rekan kerja sedang berhalangan masuk atau istirahat,

3. Membantu rekan kerja yang overload pekerjaan untuk menyelesaikan tugasnya,

4. Membantu proses orientasi karyawan baru meskipun tidak diminta,

5. Membantu mengerjakan tugas rekan kerja saat mereka tidak masuk

6. Meluangkan waktu untuk membantu orang lain berkaitan dengan permasalahanpermasalahan pekerjaan,

7. Secara sukarela mengerjakan sesuatu tanpa diminta,

8. Membantu orang lain di luar pekerjaan kita untuk memecahkan masalahnya,

9. Membantu mahasiswa dalam memecahkan masalah mereka,

Kategori 2 Consceintiousness meliputi:

1. Taat terhadap aturan kerja,

2. Datang ke kantor sesuai dengan jam datang yang ditetapkan,

3. On time saat berangkat kerja,

4. Berbicara seperlunya ditelepon,

5. Tidak suka mengosip,

6. Datang segera jika dibutuhkan,

7. Tidak suka menunda pekerjaan,

Kategori 3 Civic Virtue meliputi:

1. Toleransi terhadap sesama,

2. Tidak bosan dalam bekerja,

3. Teliti dalam bekerja,

4. Rileks dalam bekerja,

5. Tidak membesar-besarkan permasalahan di luar pekerjaannya.

Kategori 4 Cortesy meliputi:

1. Membantu mencapai tujuan organisasi,

2. Membantu memperbaiki dan mempertahankan image organisasi,

3. Selalu hadir dalam kegiatan penting,

4. Membantu mengatur kebersamaan secara organisasi,

Kategori 5 Sportmanship meliputi:

1. Menyimpan informasi atas segala kejadian atau perubahan dalam organisasi,

2. Mengikuti perubahan dan perkembangan dalam organisasi, 
3. Membaca dan melaksanakan pengumuman organisasi,

4. Mempertimbangan apa yang terbaik untuk organisasi.

\section{Manfaat Organizational Citizenship Behavior (OCB)}

Organ et, al (2006) manfaat Organizational Citizenship Behavior (OCB) antara lain : dapat meningkatkan kinerja, mempekerjakan sumber daya yang bekualitas untuk menghemat biaya dan menghasilkan kinerja terbaik, sebagai sarana koordinasi yang efektif, stabilitas kinerja organisasi konsisten, mampu adaptasi dengan cepat terhadap perubahan lingkungan kerja.

\section{Faktor - faktor Yang Mempengaruhi Organizational Citizenship Behavior (OCB)}

Organisasi yang berhasil memerlukan karyawan berkualitas dan tidak hanya mampu mengerjakan tugas biasa saja, tetapi mereka yang akan memberikan kinerja yang melebihi harapan organisasi.

Selain itu budaya organisasi, iklim kerja, kepribadian karyawan, suasana hati karyawan, dukungan organisasi, intensitas hubungan antara pimpinan dan bawahannya, lama karyawan bekerja, dan jenis kelamin karyawan juga mampu mendorong terhadap timbulnya OCB.

Jika dijelaskan lebih lanjut budaya dan iklim organisasi Konovsky dan Pugh (1994) menyatakan ketika karyawan merasakan puas terhadap pekerjaannya, maka mereka akan membalasnya dengan perasaan memiliki yang kuat terhadap organisasi seperti yang tergambar dalam organizational citizenship behavior.

Menurut Elanain (2007) "kepribadian juga memiliki peran penting dalam mendorong timbulnya OCB, ini ditunjukkan dari dari sikap kepribadian yang terbuka dan emosional yang stabil dari karyawan tersebut, maka karyawan tersebut pasti memiliki OCB yang kuat terhadap tempat kerjanya".

Hubungan antara pimpinan dan karywannya juga menjadi hal yang perlu dicermati oleh organisasi dalam mendorong timbulnya OCB, karena pada saat hubungan pimpinan dengan karyawannya ini semakin harmonis maka makin tinggi pula rasa memiliki karyawan terhadap perusahaan atau OCB karyawan semakin meningkat.

Pada penelitiannya Morrison (1994) menyatakan bahwa ada perbedaan OCB karyawan pria dan wanita. OCB pada wanita tercermin dalam perilaku in-role 
sedangkan pria tidak".I Selain itu Dienfendorff,brown, kamin, \&Lord, 2002) “ menyimpulkan bahwa wanita lebih mengharapkan kebersamaan dan tolong menolong dalam bekerja".

\section{Hubungan antara The Big Five Personality terhadap OCB}

Basrah (2012) mengkategorikan beberapa faktor yang mempengaruhi OCB terdiri dari perbedaan individu, sikap pada pekerjaan sikap, dan faktor-faktor kontekstual, dimana kepribadian termasuk dalam faktor perbedaan individu. Kepribadian dianggap sebagai salah satu faktor yang berpengaruh signifikan terhadap Organizational Citizenhip Behavior (OCB).

Kepribadian adalah hakiki yang ada pada seseorang dan sulit diubah, sehingga memiliki pengaruh yang besar dalam mempertahankan OCB (Purba dan Seniati, 2004). Selain itu penelitian Ingarianti (2014), Kappagoda (2013), Fitriyani (2013), menyatakan " bahwa kepribadian memiliki pengaruh signifikan terhadap OCB, ini ditunjukkan pada perawat yang memiliki pada dimensi kepribadian extroversion yaitu adanya sikap suka mudah bersosialisasi, berhati lembut, teliti, tepat waktu, rapi, bertanggung jawab, rileks, tidak mudah emosional, kreatif, dan ingin tahu akan memiliki OCB yang tinggi pula".

\section{HIPOTESIS}

Hipotesis penelitian ini adalah sebagai berikut: $\mathrm{H}$ : Dimensi kepribadian The Big Five Personality berpengaruh signifikan terhadap Organizational Citizenhip Behavior $(\mathrm{OCB})$.

\section{METODE PENELITIAN}

Penelitian ini deskriptif dan jenis penelitiannya explantory research dengan tujuan untuk menjelaskan hubungan antar variabel yang diteliti melalui pengujian hipotesis. Analisis yang digunakan dalam penelitian ini adalah analisis jalur (path analysis). Variabel yang akan diteliti dalam penelitian ini dapat dilihat dalam Tabel Operasional variabel dibawah ini : 
Tabel 1.1 Definisi Operasional

\begin{tabular}{|c|c|c|c|}
\hline No. & Variabel & Indikator & Item \\
\hline 1. & $\begin{array}{l}\text { Dimensi kepribadian } \\
\text { The Big Five } \\
\text { Personality }\left(X_{1}\right) \\
\text { (Robbins) }\end{array}$ & 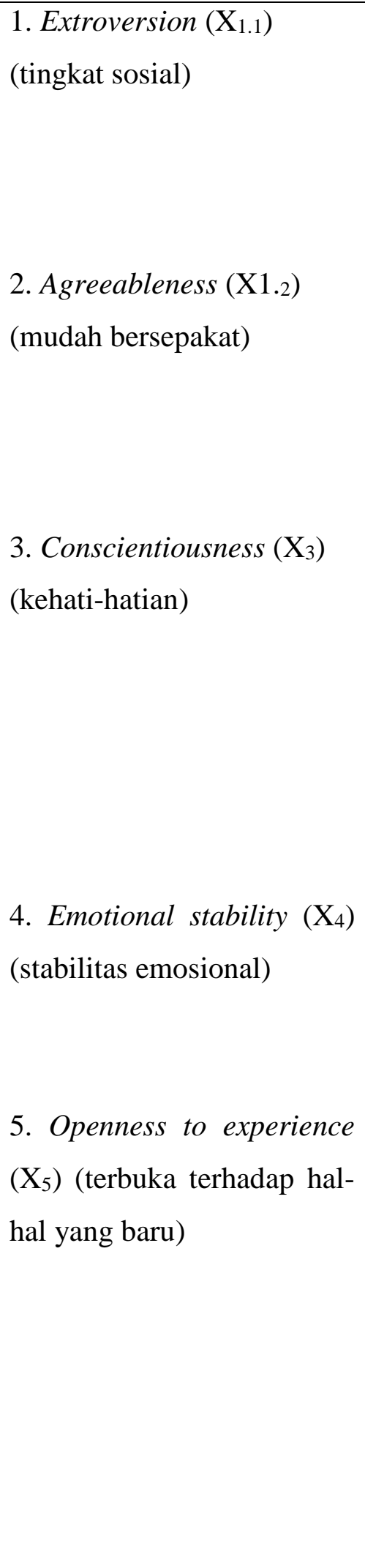 & 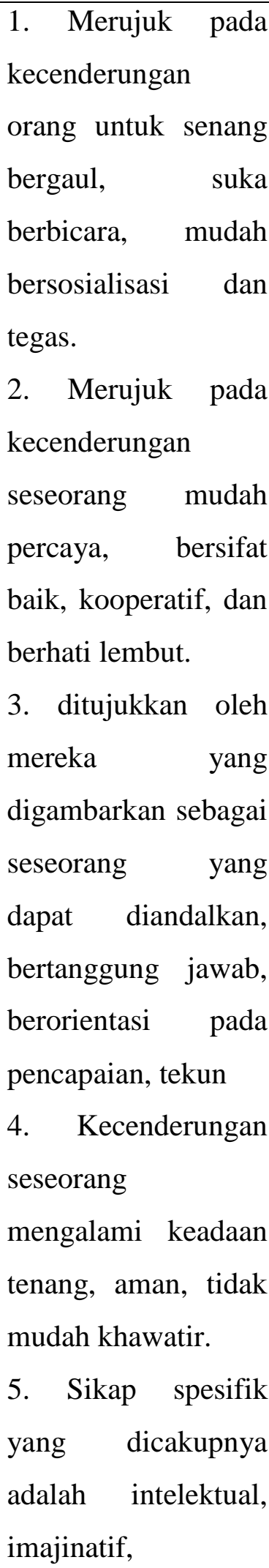 \\
\hline
\end{tabular}




\begin{tabular}{|c|c|c|c|}
\hline & & & $\begin{array}{l}\text { penasaran, dan } \\
\text { berpikiran luas. }\end{array}$ \\
\hline 2. & $\begin{array}{l}\text { OCB }(\mathrm{Y}) \\
\text { (Morison) }\end{array}$ & 1. Altruism & $\begin{array}{l}\text { 1. Suka menolong } \\
\text { 2. Menggantikan } \\
\text { peran rekan kerja } \\
\text { yang tidak masuk } \\
\text { atau istirahat, } \\
\text { 3. Membantu rekan } \\
\text { kerja yang } \\
\text { overload } \\
\text { pekerjaan untuk } \\
\text { menyelesaikanny } \\
\text { a, } \\
\text { 4. Membantu proses } \\
\text { orientasi } \\
\text { karyawan baru } \\
\text { meskipun tidak } \\
\text { diminta, } \\
\text { 5embantu } \\
\text { mengerjakan } \\
\text { tugas rekan kerja } \\
\text { saat mereka tidak } \\
\text { masuk } \\
\text { Meluangkan } \\
\text { waktu untuk } \\
\text { membantu orang } \\
\text { permain berkaitan } \\
\text { dengan } \\
\text { pekerjaan, }\end{array}$ \\
\hline
\end{tabular}




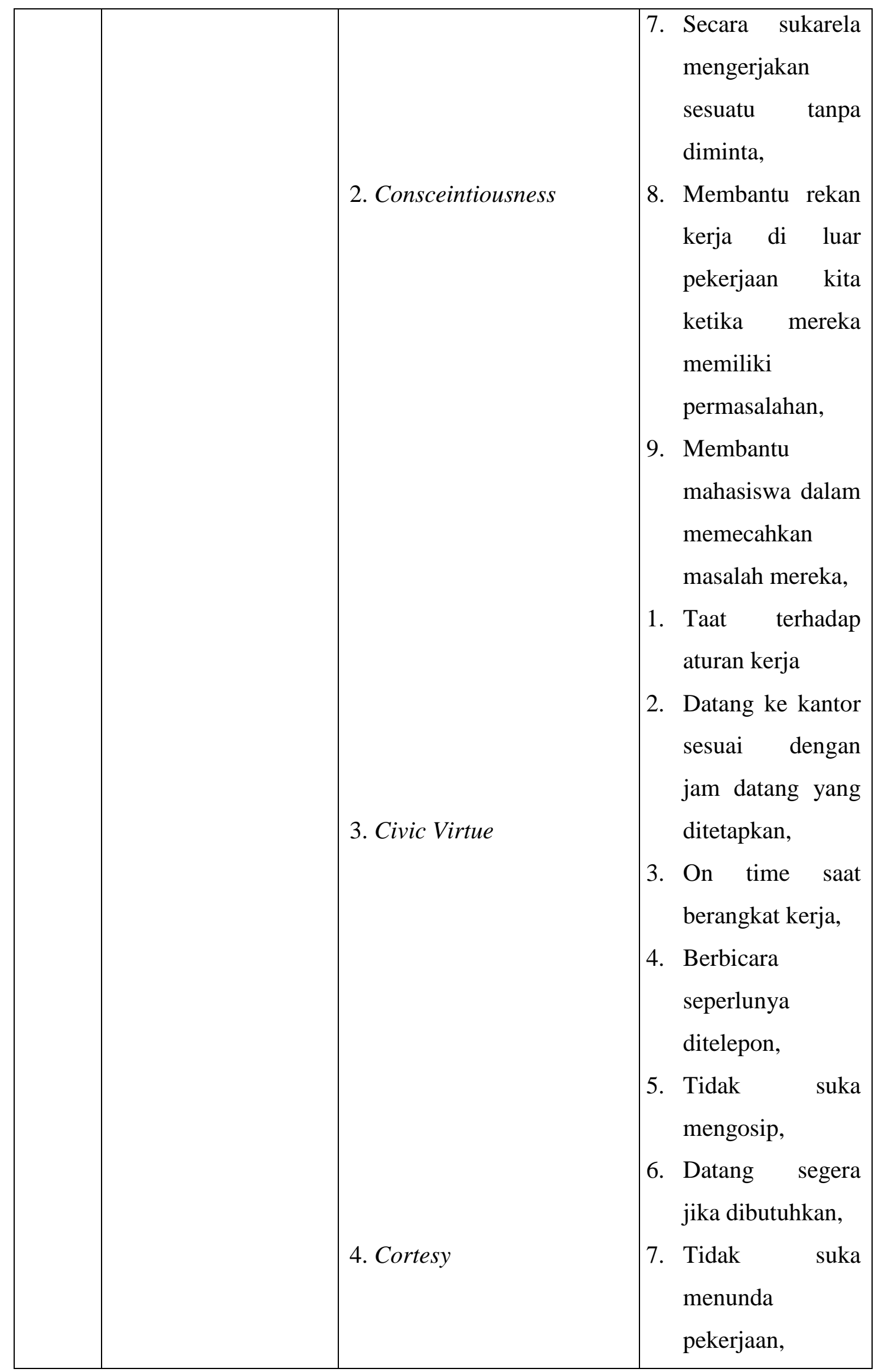




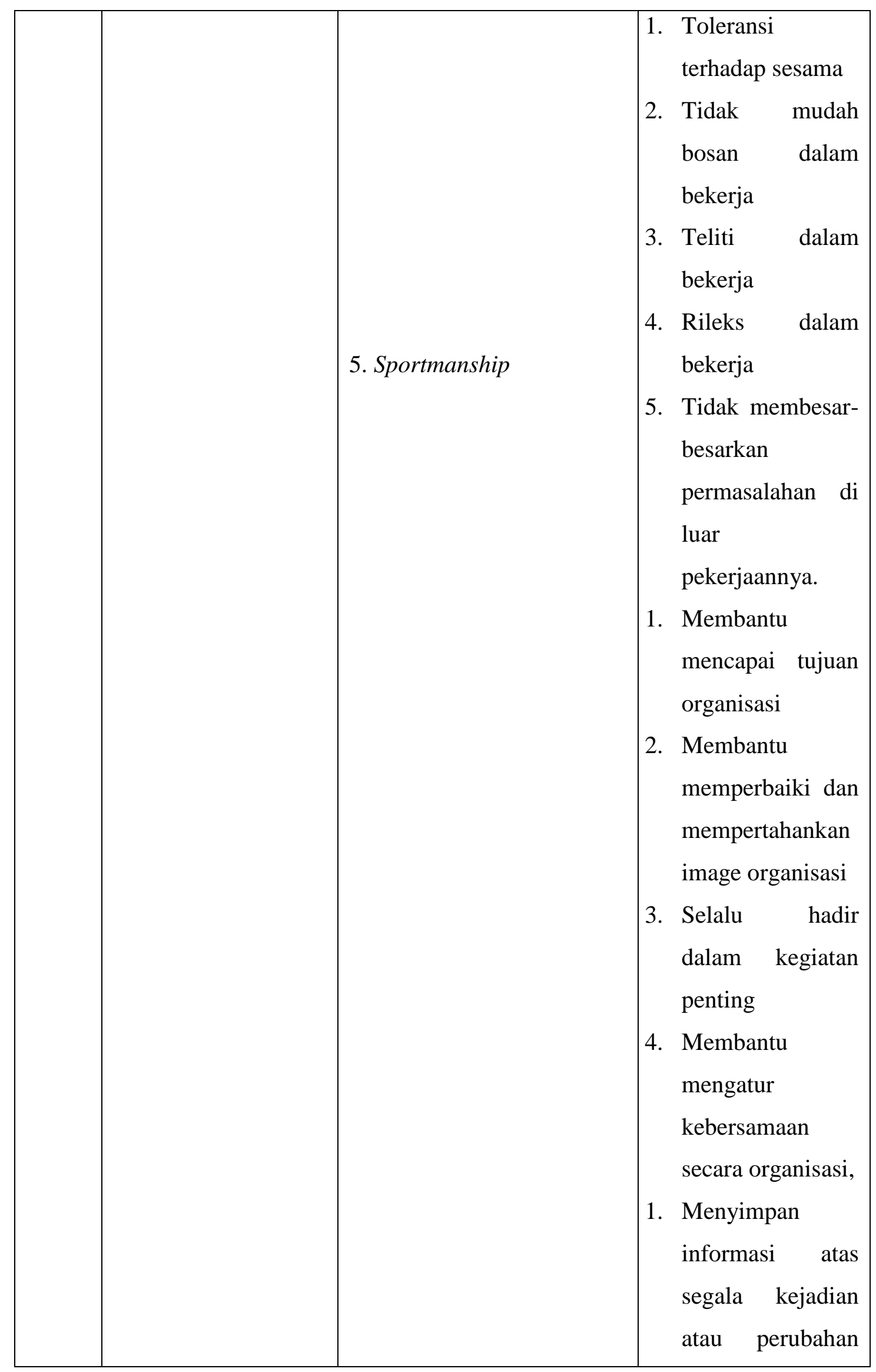




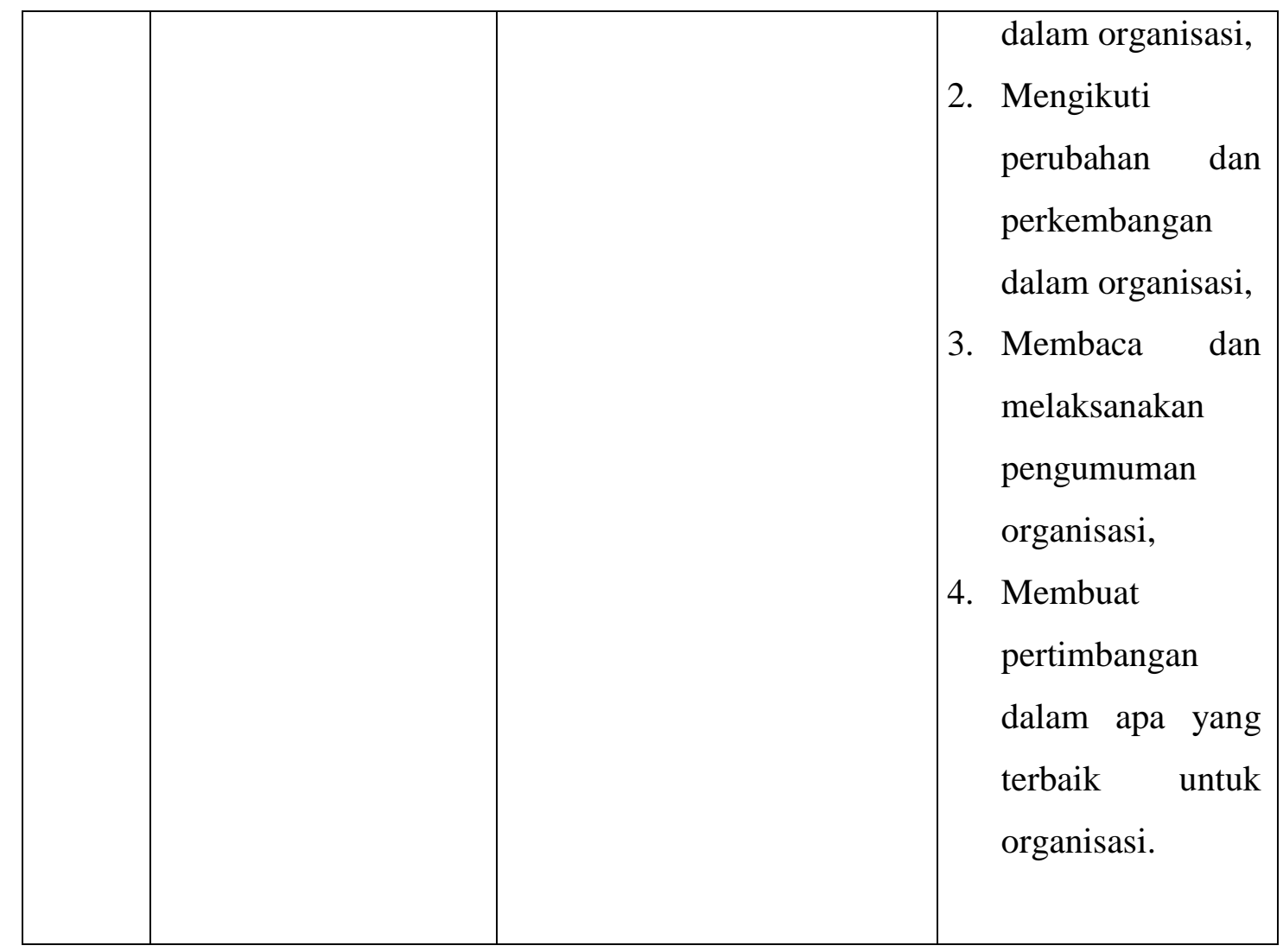

Sumber : Robbins (2008) dan Morison (1994)

\section{JENIS PENELITIAN}

Jenis penelitian ini eksplantory reasearch yang bertujuan untuk mengetahui hubungan antara variabel independen dan variabel dependen dalam penelitian tersebut.

\section{Populasi dan sampel}

Dalam penelitian ini populasinya adalah karyawan di sebuah Universitas Kadiri. Karyawan Universitas X diluar karyawan yang bertugas sebagai dosen dengan jumlah 76 orang dengan tugas pokok fungsinya masing masing yang akan diambil sebagai sampel. Teknik penarikan sampel dalam penelitian ini adalah dengan menggunakan teknik non probability sampling dengan tidak memberikan peluang yang sama terhadap populasi untuk menjadi sampel dalam suatu penelitian.

Kritria sampel dalam penelitian ini karyawan yang bertugas melayani mahasiswa, dengan jumlah 50 orang yang diambil masing-masing unit kerja yang ada di universitas tersebut. 


\section{TEKNIK PENGUMPULAN DATA}

Teknik pengumpulan data dalam penelitian ini sebagai berikut :

\section{Kuesioner}

Kuesioner adalaha teknik yang digunakan dengan cara memberikan pertanyaan dan pernyataan kepada responden, yang didalamnya dapat mewakili indikator dari tiap variabel yang akan diteliti dan pengukurannya dilakukan dengan skala Likert yang dijelaskan dalam nilai sebagai berikut : Sangat Tidak Setuju (STS), Tidak Setuju (TS), Setuju (S), Sangat Setuju (SS), Sangat Setuju Sekali (SSS).

Wawancara

Teknik wawancara dilakukan semata-mata hanya untuk mengetahui data sekunder seperti profil perusahaan, gambaran umum perusahaan, daftar karyawan dan lainnya yang terkait dengan tempat penelitian.

\section{TEKNIK ANALISIS DATA}

Teknik analisis data yang digunakan dalam penelitian ini adalah dengan menggunakan software SMARTPLS yang terdiri dari : merancangan sebuah model struktural (inner model) yang didasarkan dari rumusan masalah atau hipotesis yang ada dalam penelitian ini, merencanakan model pengukuran (outer model) yang bertujuan untuk mengetahui hubungan tiap indikator dari variabel laten yang ada, dan uji hipotesis (Resampling Bootstraping).

\section{ANALISIS DATA DAN PEMBAHASAN}

Penelitian ini bertujuan untuk mengetahui pengaruh Dimensi Kepribadian the big five personality sebagai variabel X terhadap Organizational Behavior Citizenship (OCB) sebagai variabel Y.

Analisis data yang digunakan adalah analisis Partial Least Square Structural Equation Modelling (PLS SEM) untuk membuktikan apakah ada pengaruh Dimensi Kepribadian the big five personality sebagai variabel $\mathrm{X}$ terhadap Organizational Behavior Citizenship (OCB) sebagai variabel Y. 


\section{Analisis Partial Least Square Structural Equation Model (PLS-SEM)}

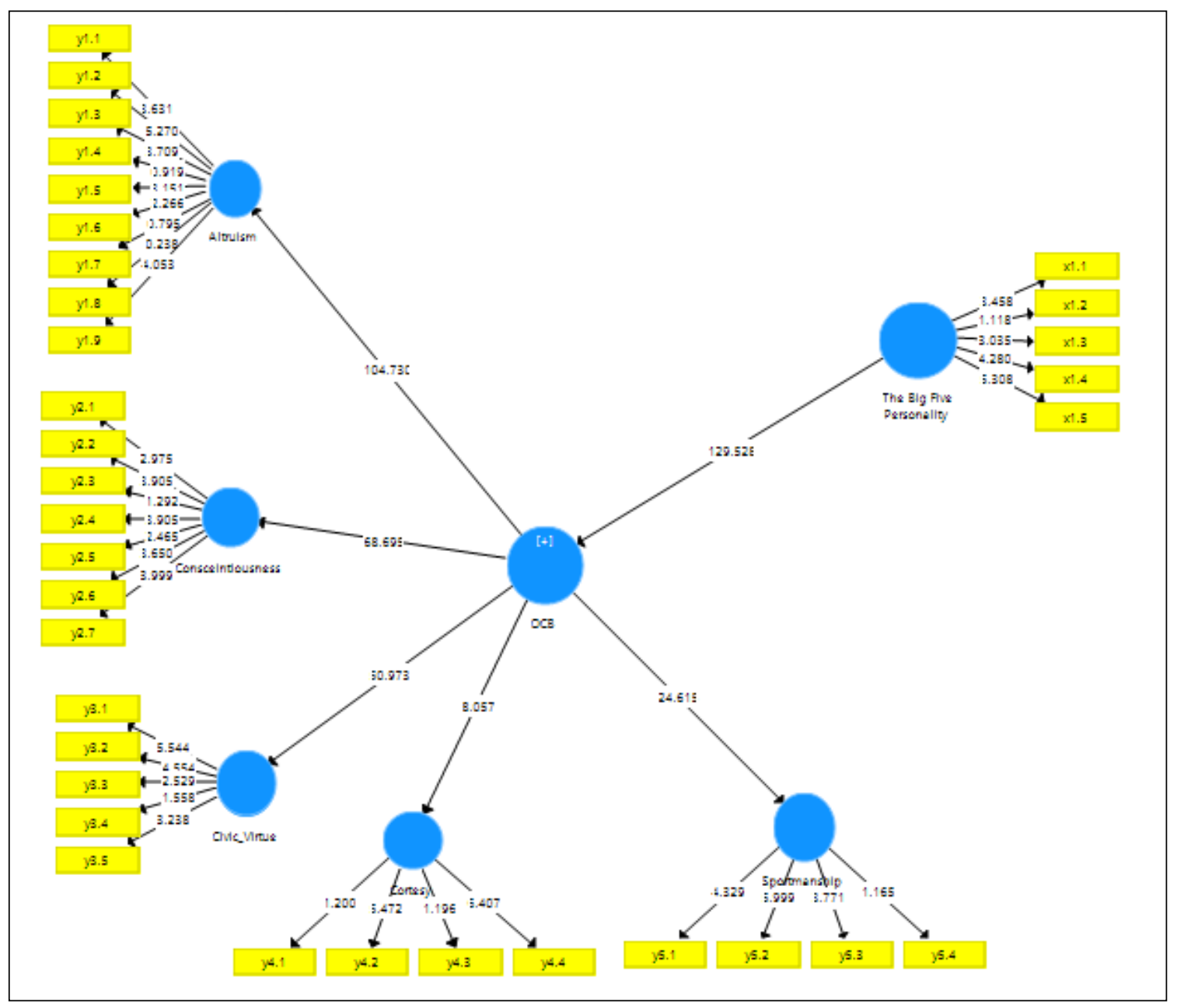

Berdasarkan hasil analisis menggunakan PLS SEM, didapatkan kesimpulan bahwa dimensi kepribadian the big five personality berpengaruh terhadap Organizational Behavior Citizenship. Kesimpulan ini didapatkan dengan mempertimbangkan nilai $\mathrm{t}$ statistik pada dimensi kepribadian the big five personality sebesar 129,52 dimana nilai ini lebih besar dari 1.96 .

Variabel Organizational Behavior Citizenship disusun oleh 5 variabel yaitu Altruism, Civic Virtue, Consceintiousness, Cortesy, dan Sportmanship. Dari kelima variabel penyusun Organizational Behavior Citizenship, variabel Altruism memiliki kontrobusi paling besar karena memiliki nilai t statistik yang paling besar dibandingkan dengan variabel yang lain. 
Tabel 1. Kontribusi setiap variabel

\begin{tabular}{|l|c|c|}
\hline Path Koefisien & T Statistics (|O/STERR|) & P Values \\
\hline OCB -> Altruism & 104,73 & 0,000 \\
\hline OCB -> Civic_Virtue & 50,973 & 0,000 \\
\hline OCB -> Consceintiousness & 68,695 & 0,000 \\
\hline OCB -> Cortesy & 8,057 & 0,000 \\
\hline OCB -> Sportmanship & 24,615 & 0,000 \\
\hline big five personality -> OCB & 129,528 & 0,000 \\
\hline
\end{tabular}

Dimensi kepribadian the big five personality yang terdiri dari extroversion (X1), agreeableness (X2), concientiousness (X3), emotional stability (X4), dan openness to experience (X5). Variabel openness to experience (X5) merupakan variebel yang memiliki kontribusi paling besar dalam penyusun kepribadian. Dengan hasil ini apabila ingin terjadi peningkatan Organizational Behavior Citizenship dapat dilakukan dengan meningkatkan kepribadian the big five personality khususnya peningkatan openness to experience.

Tabel 2. Kontribusi setiap indikator pada variabel big five personality

\begin{tabular}{|l|c|c|}
\hline Path Koefisien & $\begin{array}{c}\text { T Statistics } \\
(\mid \text { O/STERR } \mid)\end{array}$ & P Values \\
\hline $\mathbf{x 1 . 1 < - ~ X ~}$ & 3,458 & 0,001 \\
\hline $\mathbf{x 1 . 2 < - ~ X ~}$ & 1,118 & 0,264 \\
\hline $\mathbf{x 1 . 3 < - ~ X ~}$ & 3,035 & 0,003 \\
\hline $\mathbf{x 1 . 4 < - X}$ & 4,28 & 0,000 \\
\hline $\mathbf{x 1 . 5 < - ~ X ~}$ & 5,308 & 0,000 \\
\hline
\end{tabular}

Hasil penelitian ini selaras dengan penelitian yang dilakukan amperawan et all (2016) bahwa dimensi kepribadian the big five personality berpengaruh terhadap Organizational Behavior Citizenship. Amperawan menjelaskan bahwa kondisi ini dikarenakan kepribadian yang dikembangkan dan diterapkan oleh para dosen di UIN Suska Riau dapat mempengaruhi kegairahan aktivitas akademik dan non akademik sehingga dosen berusaha optimal mencapai tujuan perguruan tinggi.

Teori diatas juga dapat diadopsi sebagai dasar adanya pengaruh big five personality berpengaruh terhadap Organizational Behavior Citizenship dalam kasus pelayanan terhadap mahasiswa. Pengembangan kepribadian oleh karyawan akan dapat 
berdampak pada peningkatan kegiataan pelayanan kepada mahasiswa. Hal ini dikarenakan pelayanan mahasiswa merupakan pekerjaan yang sangat terkait dengan kepribadian diri dari individu pekerja itu sendiri dalam melayani mahasiswa, dimana kunci kesuksesan dari pekerjaan ini tergambar dari kemampuan interaksi. Untuk dapat berinteraksi dengan baik, maka diperlukan suatu pengembangan kepribadian.

\section{DAFTAR PUSTAKA}

Basrah, Hendryadi. 2012. Faktor yang mempengaruhi OCB http://teorionline.wordpress.com/2012/03/28/faktor-yang-mempengaruhi-ocb/. diakses pada 5 Januari 2018.

Ingarianti, Tri Muji. 2014. "Hubungan Antara Kepribadian (The Big Five Factor Personality) dengan Organizational Citizenship Behavior pada Karyawan”.

Desi dan Veronika. " Analisis Pengaruh The Big Five Personality Terhadap Organizational Citizenship Behavior (OCB) dan Kinerja Perwat Di RS Santa Clara Madiun”. Jurnal Manajemen Indonesia. Vol. 15 No.1 April 2015.

Diefendorff, J. M., Brown, D. J., Kamin, A. M., and Lord, R. G. (2002) “Examining the roles of job involvement and work centality in predicting organizational citizenship behaviors and job performance”. Jurnal Of Behavior, 23(1), 93108.

Elanain, H.A. (2007). Relationship Between Personality and Organizational Citizenship Behavior: Does Personality Influence Employee Citizenship? International Review of Business Reaserch Papers, 3(4), 31-43.

George, J.M. and Bettenhausen, k. (1990). Understanding Prosocial Behavior, Sales Performance and turnover: A Group - level analysis in service context. Jurnal of Applied Pschology, 75, 698-790.

Morrison, E. W. (1994). Role Definition and Organizational Citizenship Behavior: the importance of The Employee'es Perspective. Academy of Management Journal, 37(6), 1543-1567.

Robbins, Stephen P,; Judge, Timothy A. (2008). Perilaku Organisasi Buku 1, Jakarta: Salemba Empat. Hal. 126-127

Robbin, S, P., \& Judge, T. (2013). Organizational Behaviour. USA: PEARSON. 
Sambung, R., \& Iring. (2014). Pengaruh Kepribadian Terhadap Organizational Citizenship Behaviour dengan Komitmen Organizational sebagai Variabel Intervening, Manajemen dan Akuntansi, 1-16.

Pareke, Fahrudin Js. “ Dimensionalisasi Perilaku di Luar Peran Kerja (extra-role behavior)". Jurnal Bisnis dan Ekonomi. Vol. 11 No.2 September 2004.

Organ, D. W., Podsakof, P. M., and Mackenzie, S. B. (2006). “Organizational Citizenship Behavior: Its nature, antecedents, and consequences”. California: Sage Publication. 